


\section{弹性搭建 \\ 一一首尔解放村商业街区微更新设计 FLEXIBLE CONSTRUCTION: MICRO-RENEWAL DESIGN IN THE HAEBANGCHON NEIGHBORHOOD IN SEOUL}

吕小辉, 徐夕然, 张旸, 贾静(1

Xiaohui LV, Xiran XU, Yang ZHANG, Jing JIA ${ }^{(1)}$

吕小辉为西安建筑科技 大学艺术学院副院长、 副教授; 徐夕然、张旸 为西安建筑科技大学艺 术学院硕士研究生; 贾 静为西安建筑科技大学 艺术学院本科生。

2) 2017年由国际建筑师协 会 (UIA) 举办的第26届 国际学生与青年建筑师 竞赛影目为: “后人类

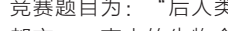
都市一一南山的生物合 成末来”, 旨在为位于 韩国首尔市南山脚下城 乡边缘地区的解放村征 集更新方案。竞赛要求 以一种自下而上、渐进 式的城市更新策略, 鼓 励社区参与及可持续性 再生, 此保护现有的 城古, 保护现有的 城市肌埋和当下社区的 完整性, 并促进当地经 济的振兴。

(1) Xiaohui Lv, Xiran Xu and Yang Zhang, and Jing Jia, the Vice Dean and Associate Professor,

postgraduates, and

an undergraduate

of College of Arts

at Xi'an University

of Architecture

and Technology,

respectively.

“弹性搭建” 模式下街区 中丰富多彩的活动。

A variety of activities introduced into the neighborhood through the flexible construction model.

\section{项目背景}

由于历史发展及形成过程的特殊性, 城市传统街区往往拥有复杂多元的社会、经 济和文化环境。尽管街区空间形式与功能混 杂, 且充斥着各种各样的矛盾, 但却不乏富 有活力的生活场景。基于对自上而下的大规 模拆建性规划改造方式的反思, 本文旨在探 索一种更具弹性和可持续性的空间干预模 式, 这种模式既可有效缓解各种矛盾, 又可 保留社区原有的活力。以2017年国际建筑师 协会 (UIA) 国际学生与青年建筑师竞赛方 案 $^{2}$ ——韩国首尔解放村商业街区微更新设计 为例, 其通过 “弹性搭建” 这样一种低成本 且高效的微干预方式, 对街区和公共空间进 行有机更新, 以打造更具包容性、多样性和 公平性的活力街区 (图1)。

\section{场地分析}

解放村位于首尔南山脚下的城市边缘地 区, 占地约 $2 \mathrm{~km}^{2}$, 是一个集居住、商业、旅 游等功能于一体的复合型城市传统街区。20 世纪70年代, 随着城市的不断发展, 大批城 镇居民迁入解放村。截至2015年, 当地人口 共计约12000人。
素月路20街是解放村中主要的商业街, 也是此次更新设计的核心区域, 街道宽约 5 7.5m, 面积达21 600 m² (图2)。沿街 两侧多为三层的居住与商业建筑, 街道中部 有市场、学校和教堂。在这里, 居民、商户 和游客混杂交织, 空间使用形式丰富多样, 生活、生产气息浓厚（图3）。但随着时代变 迁, 解放村已与这里的第一代居民一起迈入 了暮年, 建筑老旧、设施破败, 加之缺之统一 的规划, 多种矛盾和问题逐渐突显 (图4), 包括:

（1）人车混行：高峰时段街道出现不同 程度的拥堵现象;

（2）市集混乱：沿街住户、商户侵占 街道空间现象严重, 与流动小商贩混杂在一 起, 导致业态低迷, 缺乏秩序;

（３）活动空间类型单一、设施匮之: 街 区活动空间以小型不规则空间居多, 缺乏大 型公共空间和高品质公共绿地。活动设施匮 之, 无法满足周边居民、商户、游客的日常 使用需求。

\section{方案策略}

针对以上问题, 项目提出了如下 4 个策略 (图5):
https://doi.org/10.15302/J-LAF-20170512 收稿时间 RECEIVED DATE / 2017-09-20 中图分类号 / TU986

文献标识码/B
摘要

项目针对韩国首尔市解放村商业街区中人车混行、市集

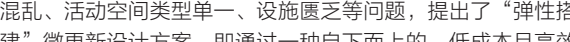
建”微更新设计方案, 即通过一种自下而上的、低成本且高交 的模块化设计势, 对街区进行有机更新, 既可有效缓解各种 矛盾, 又可保留街区原有的活力。“弹性搭建”项目尝试探索 一种更具弹性和可持续性的空间干预模式, 以期为城市传统街 区的更新提供一种新思路。

关键词

传统街区; 微更新; 弹性搭建；模块化设计

\section{ABSTRACT}

To address the problems of lacking traffic planning, informal street vending, and deficient public space and amenities in the Haebangchon neighborhood of Seoul, South Korea, this project proposes a micro-renewal plan of "flexible construction" to transform the neighborhood in a bottom-up way. This costefficient approach of modular design will alleviate these conditions and improve neighborhood vitality. The project aims to develop a more resilient and sustainable spatial design for urban renewal.

\section{KEY WORDS}

Traditional Neighborhood: Micro-Renewal; Flexible

Construction; Modular Design

整理 田乐 王少

译黄延峰 萨拉 $\cdot$ 雅各布斯

EDITED BY Tina TIAN Ying WANG

TRANSLATED BY Yanfeng HUANG Sara JACOBS

基金项目：陕西省自然科学基础研究项目（2017JM5128) 陕西省社会科学基金项目（2016J036）

Research Funds: Natural Science Basic Research Project of Shaanxi Province (2017JM5128)

Social Science Fund Project of Shaanxi Province (2016J036) 


项目地址:
韩国首尔市龙山区解放村
项目面积:
21 600m²
项目团队:
只小辉、徐夕然、张旸、贾静
设计时间:
2017年3月
所获奖项:
2017第十三届全国高校景观设计毕业作品展LA先锋奖景观
设计奖
LOCATION:
Haebangchon, Yongsan District, Seoul, South Korea
AREA (SIZE):
21,600 m $^{2}$
PROJECT TEAM:
Xiaohui LV, Xiran Xu, Yang Zhang, Jing Jia
DESIGN PERIOD:
March, 2017
AWARD:
Landscape Design Award of The 13th LA Frontiers Award
- Chinese Landscape Architecture Graduate Works
Exhibition 2017

(3) PPGIS是一种基于地理 信息系统 (GIS) 的公众 参与形式, 其通过使用 图像及其他空间和视 国像及其他空间和视觉 工具, 将GIS和地图等 业实践引入地方层面, 鼓励更广泛的公众参与 和来自地方层面、非政 府团体的知识产出。

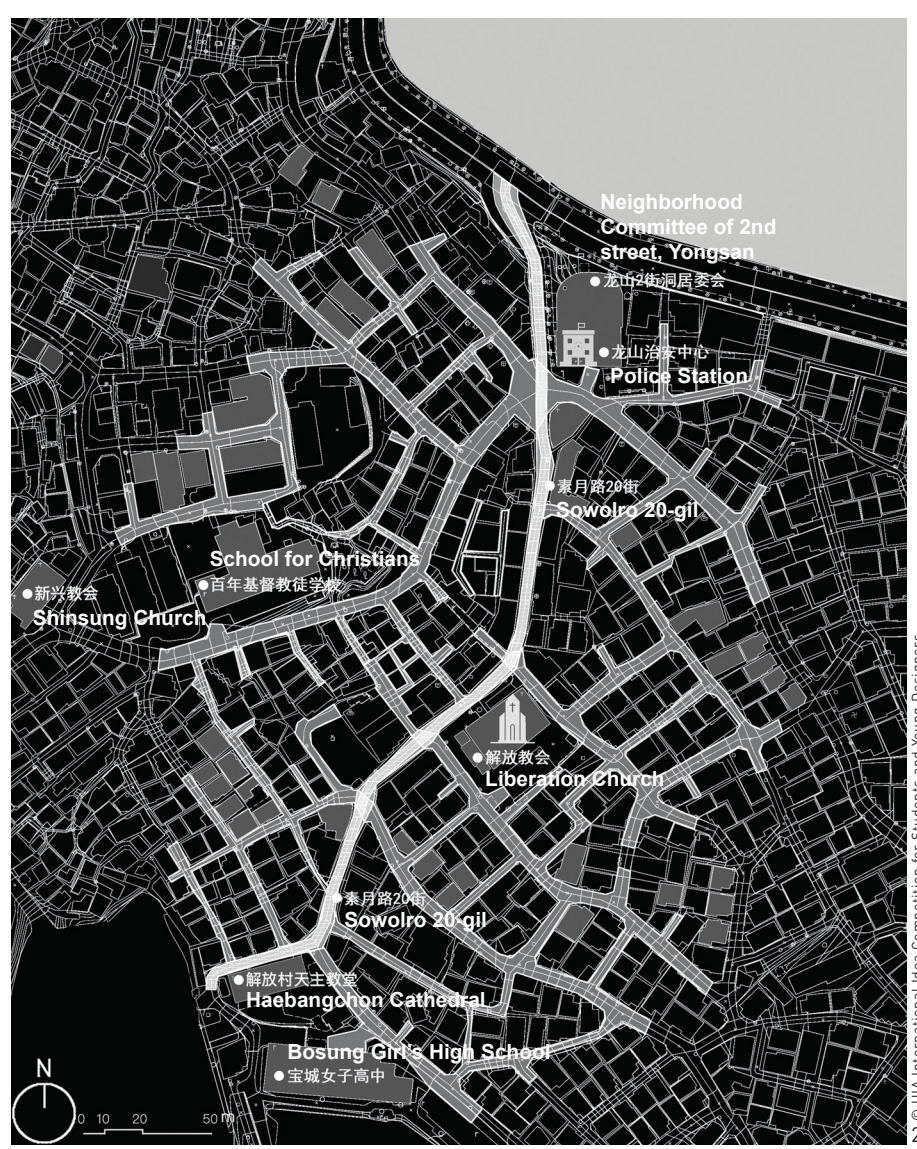

（1）整合居住、商业及游览三大功能

公共空间和社会生活之间的相互依赖 性，使得社会活动成为公共空间设计的关键 要素。解放村街区多元复杂, 承载的公共生 活丰富多样，这些生活自发无序、混杂交 织。通过观察和分析当地居民、商户、游客 日常的生活、售卖、游览方式及其他活动行 为, 可以将空间分为日常交通、交往聚集、 休闲娱乐、休鄎交流、资讯获取、商品展 示、市集贸易等类型。只有厘清了街区中的 各类活动, 才能创造出支持行为活动的空间 模式。

（2）梳理空间，打造连续、完整、多层 次的生活和游览体验

由于商业街道路狭窄、人车混行、沿 街界面功能混杂, 致使街区无法在居民出 行、商业售卖以及游览观光方面提供完整的 体验。设计将根据街区的交通流线、空间格 局、活动分布现状, 对街区空间进行梳理、 分类，并根据空间位置、大小和形状，因地 制宜地进行弹性搭建, 形成一个兼顾生活、 休闲和商业服务的连续、完整、多层次的空 间系统，不仅能够提升居民生活和出行环境 的品质, 也将丰富游客观光体验形式。

（３）延续居民生活和当地文化

解放村作为一个传统街区, 有着复杂、
多元的社会和文化环境，充满着富有活力的 生活场景, 承载着城市发展的记忆。方案建 议将居民的生活空间由现有的屋里弄堂适度 延伸至更大尺度的街巷中，一方面拓展了居 民的活动空间, 可创造更多彼此交流、交往 的机会, 增强社区凝聚力和归属感; 另一方 面也可使外来游客更近距离地接触和感受传 统街区的生活方式。

（4）构建数据平台, 鼓励公众参与

运用互联网、PPGIS ${ }^{3}$ 、虚拟现实等技 术, 构建一个基于网络的解放村弹性搭建支 持系统, 以移动设备应用程序的方式呈现。 通过PPGIS和在线论坛可了解居民、商户和 游客的使用意愿，收集他们在街区日常生活 中使用网络服务时留下的数字轨迹, 从而掌 握公众的日常活动行为和搭建模块的使用情 况。同时，借助数据可视化技术进行虚拟搭 建, 可使公众更好地理解和参与搭建选址和 设计的全过程, 进而引导更为合理的模块布 局和搭建（图6）。

实施途径

“弹性搭建”是一种适用于不同 空间类型的，可满足生活、生产、生态 等多种功能的空间介入模式, 其利用
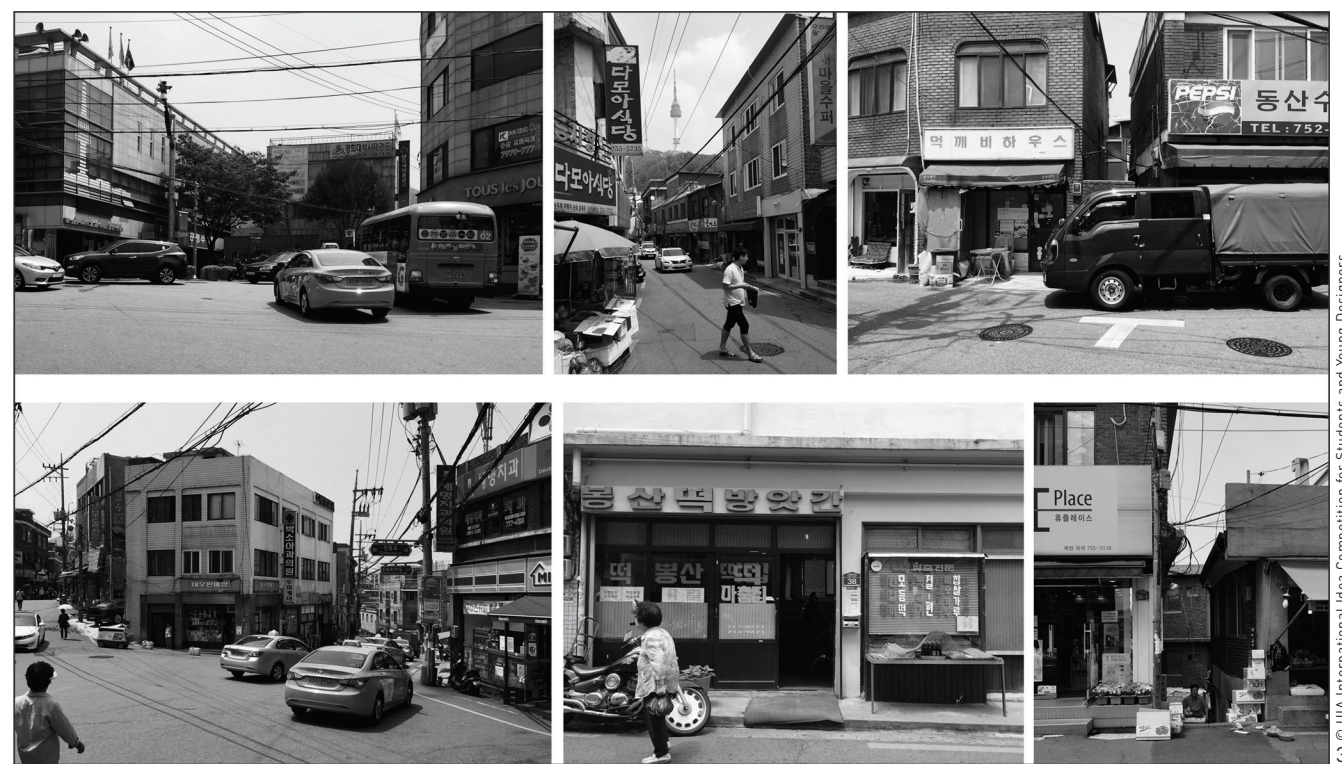
Site map of the Haebangchon neighborhood

The existing Sowolto 20-gil

The neighborhood is confronted with several problems, including lack of traffic planning informal street vending, and deficient public space and amenities.
“-” “L” “T” “ $F$ ” “ $Y$ ” “ $K$ ” “十” 等形状的金属连接件将多根1.5m长的竹笔 相互组合, 辅以木板、晴雨篷、立体绿化种 植袋等基础配件。这种搭建模式具有以下特 点: 1) 适用性与多功能性: 具有功能多样、 成本低廉、可拆卸移动、可操作性强、易于 推广等优点, 适用于街区中各种尺度的空间 类型, 并可根据实际需要进行弹性调整。2) 自主性：鼓励当地居民和商户参与到公共空 间的改造中，以增强社区凝聚力和主人翁意 识。3) 最小干扰性：搭建模块将对当地的物 质空间和生态环境的干扰降到最低 (几乎不 会造成任何破坏），实现对街区的微干预和 微更新。

通过深入观察分析街区居民、外来游
客的活动类型和方式，以及对整个街区空间 格局进行分析，方案提取出了5种街区空间 类型：街市公共空间、街道空间、街区公共 空间、街巷尽端公共空间和街巷微型公共空 间, 并分别设计了5种类型的搭建模式来满足 其各自不同的使用需求。

（1）街市公共空间的早市模块：清晨， 在预置的基础构件上快速搭建好带有彩色 顶棚的早市模块，不同色彩代表着不同的 商品种类, 此种搭建在对摊贩进行归类的 同时大大方便了人们的采购，提高了生活效 率 (图7)。

（2）街道空间的路挡模块: 早市过后, 道路恢复车辆通行，在预置基础构件上安装 路挡杆和晴雨篷, 形成路挡模块。晴雨篷收
放便捷，路挡杆在不占用道路空间的前提下 巧妙地进行人车分流，不仅给司机和外来旅 游者以明确的导向性, 同时也增强了行车安 全（图8）。

（3）街区空间的社交模块：街区内公共 空间匮乏, 在街区中较大的场地进行模块化 搭建，并在纵向空间上进行复制加建，以节 约地面资源。模块空间可用于居民集会、娱 乐交往、休䕀、锻炼、阅读看报，以及其他 各种自发性活动, 以促进交往, 加强邻里关 系。同时模块可支持立体绿化, 有助于为 整个街区创建更加怡人的生活及活动空间 (图9)。

（4）街巷尽端空间的舞台模块: 在节假 日时，人们可搭建由多个模块构件组成的临

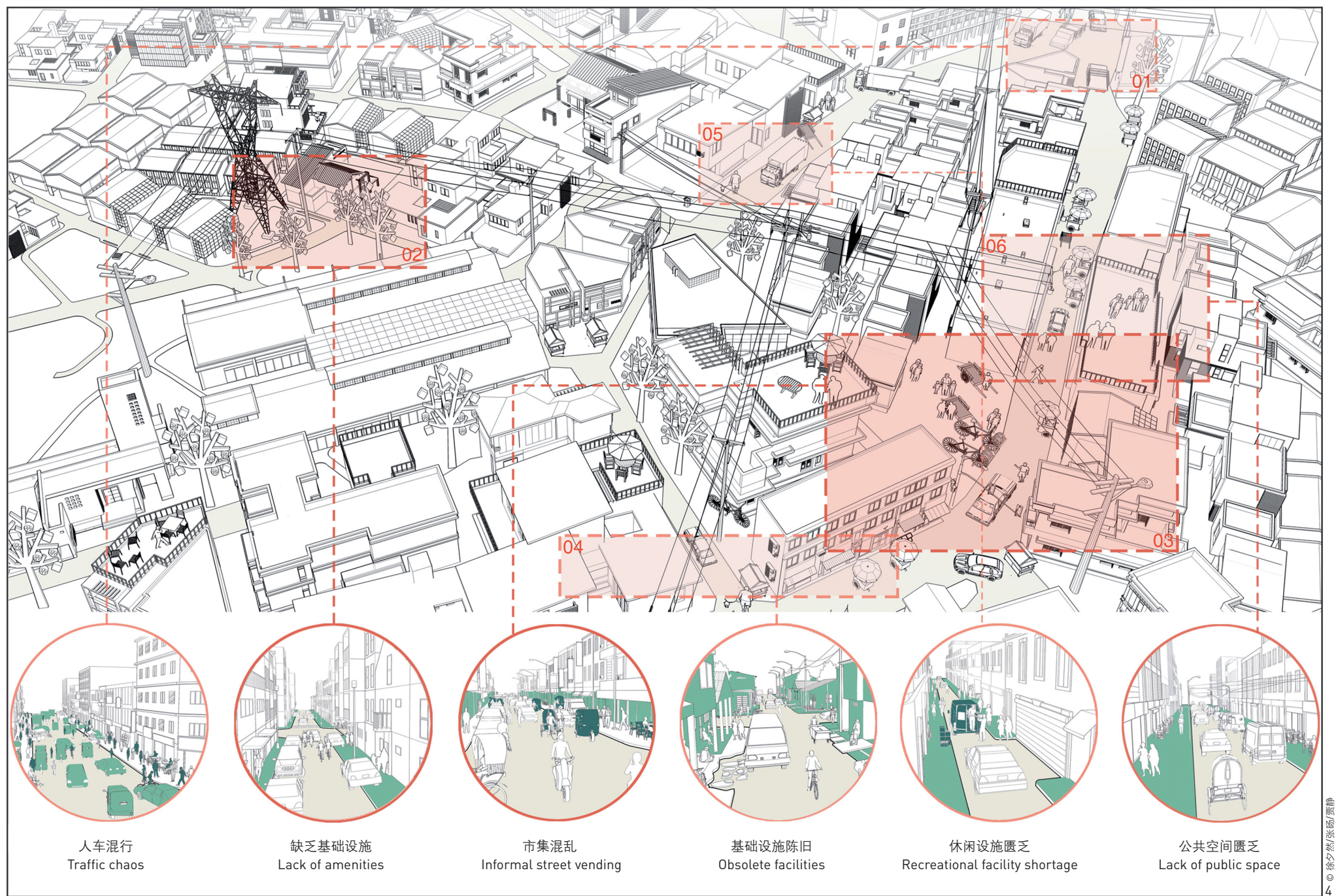


1、整合商业、居住和旅游功能

Integrating commercial, residential, and tourist functions

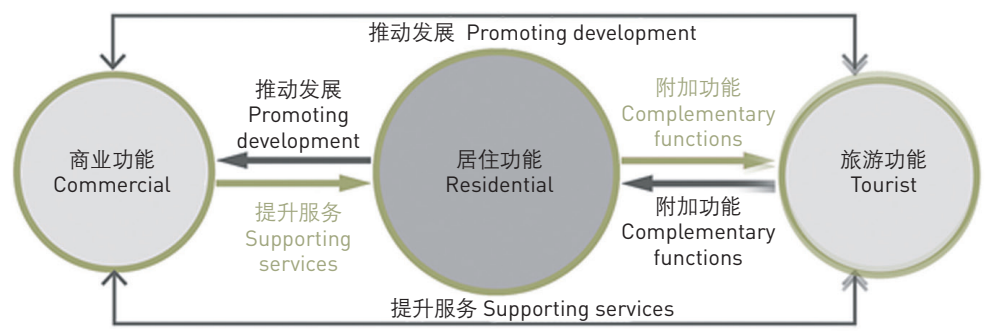

3. 延续居民生活和当地文化

Improving residents' living conditions and celebrating local culture

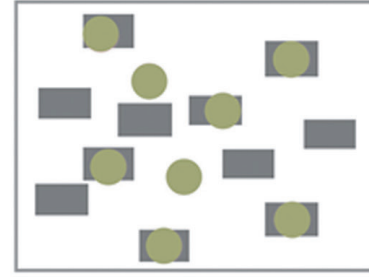

将现有的屋里弄堂生活空间

Existing alley scale of residents' living space

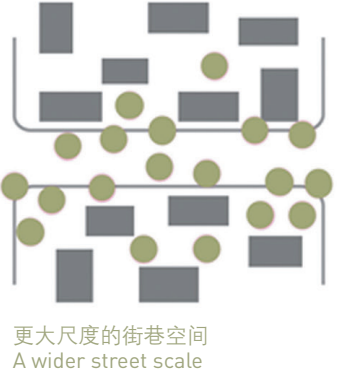

更大尺度的街巷空间
2, 打造连续、完整、多层次的生活和游览体验

Creating a continuous, integrated and multi-layered living and tour experience

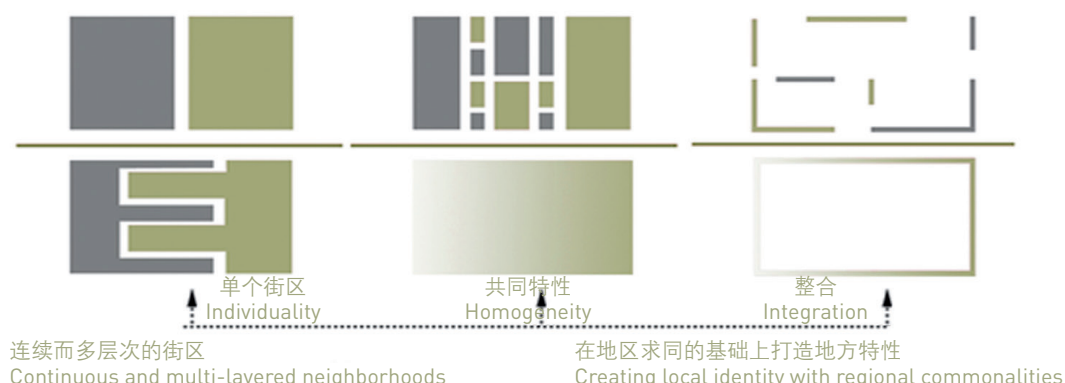

4. 构建数据平台, 激发公众参与热情

Establishing a data platform to motivate public engagement

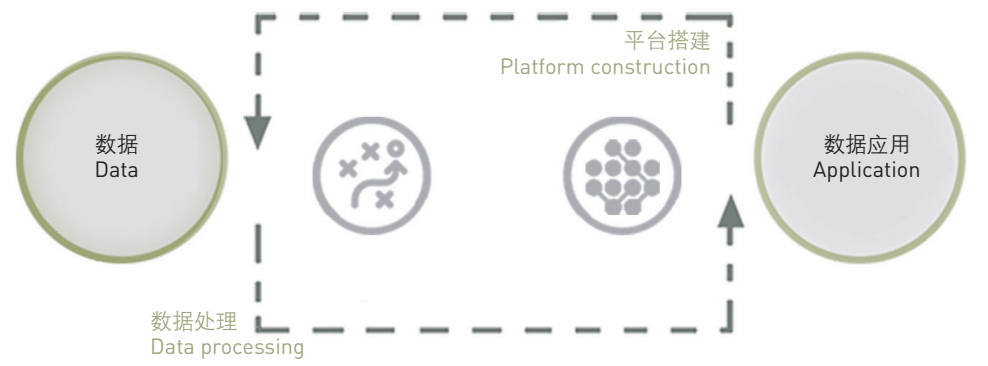

时舞台, 为街区提供庆祝、表演、集会的空 间，为文化交流、节日纪念品售卖等提供场 所（图10）。

（5）街巷微型空间的游僁模块：在街巷 微型公共空间中利用道路一侧的边角零星空 间，在预置的基础构件上增加游鄎模块，形 成小型公共空间，可供使用者在此短暂停留 休鄎或玩要（图11）。

\section{结语}

在城市传统街区的更新中，尽管每个 地区的复杂性和独特性各异, 但这种适应性 强、功能复合、自主性高、干扰性小的弹性 搭建模式适用于各类街区和公共空间的改 善, 可提升传统街区的宜居性, 活化传统街 区本身的特色，同时加强地区身份认同感。 通过解放村城市更新方案，笔者希望“弹性
搭建” 能够作为对空间干预模式的探索， 为城市传统街区的更新提供一种新的思 路。LAF

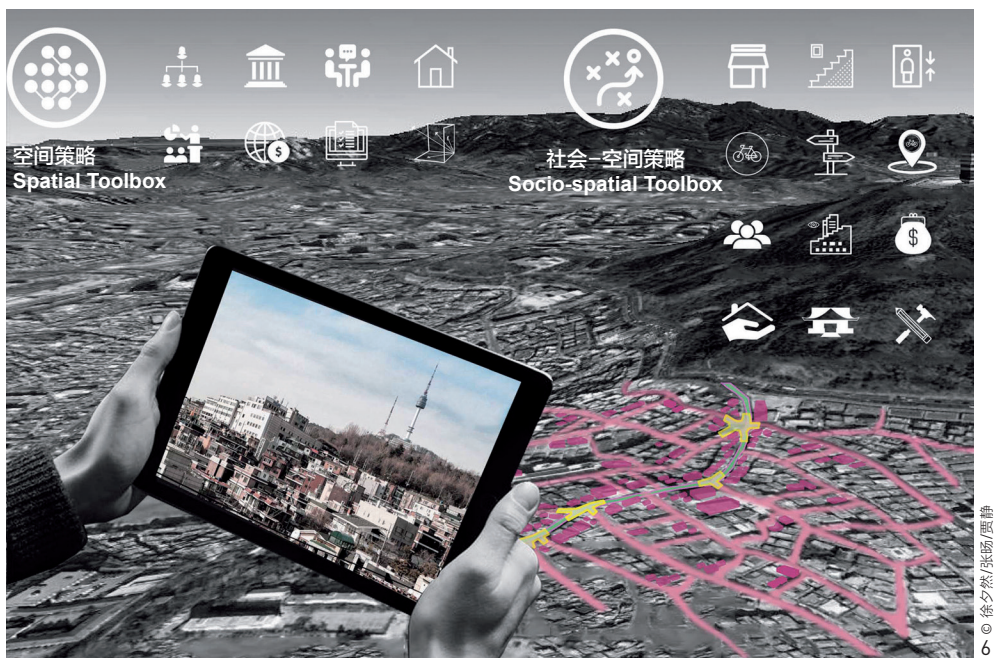

Themed with "Posthuman Urbanity: A Biosynthetic Future on Namsan," the 2017 International Idea Competition for Students and Young Designers held by the International Union of Architects (UIA) aimed to collect renewal proposals for Haebangchon, a neighborhood located at the urban edge of Namsan, Seoul. The competition encouraged a gradual strategy of urban renewal from the bottom up and a more socially sustainable model of urban regeneration to preserve the existing urban fabric and retain the current community intact, while fostering

5. 设计策略框架 6. 数据平台在项目中的 应用可激发公众参与 的热情。

5. Framework of design strategies

6. The data platform applied in the project may motivate public engagement. 


\section{Background}

Urban traditional neighborhoods are complex social, economic, and cultural spaces due to each's specific historical development. Despite the contradictions caused by mixed spatial structures and functions, these complexities create neighborhoods that are vibrant places. This project explores a more resilient and sustainable redevelopment instead of top-down approaches of massive demolition and construction, and seeks to preserve the neighborhoods' vitality. It uses the project, Micro-renewal Design of Haebangchon Neighborhood in Seoul as an example, which was first conceived as part of the 2017 International Idea Competition for Students and Young Designers held by the International Union of Architects $(U I A)^{2}$, and proposes cost-efficient smallscale interventions through "flexible construction" to create a more inclusive, diverse, and fair neighborhood (Fig. 1).

\section{Site Analysis}

Located at the urban edge of Namsan, Seoul, Haebangchon is an urban traditional neighborhood covering two square kilometers, with a mix of residential, commercial, and tourist functions. Since the 1970s, many new urban dwellers have settled in Haebangchon, resulting in the local population increasing to a total of 12,000 by 2015.

Sowolro 20-gil (street) is the main commercial street in Haebangchon. It has a width of five to seven meters and covers an area of 21,600 square meters (Fig. 2). This street was chosen for the redesign because of its proximity to residential and commercial buildings, along with schools, markets, and churches in the central area. The diversity
7-2. 搭建模式与效果图. 可轻松搭建的带有彩色顶棚的早市模块优 化了街市的结构, 大大提高了人们的采购效率。
7-1. Morning market modules in traditional marketplace

7-2. Construction model and rendering: The morning modules with easily installed canopies in different colors could improve the market's organization, making it more convenient for consum

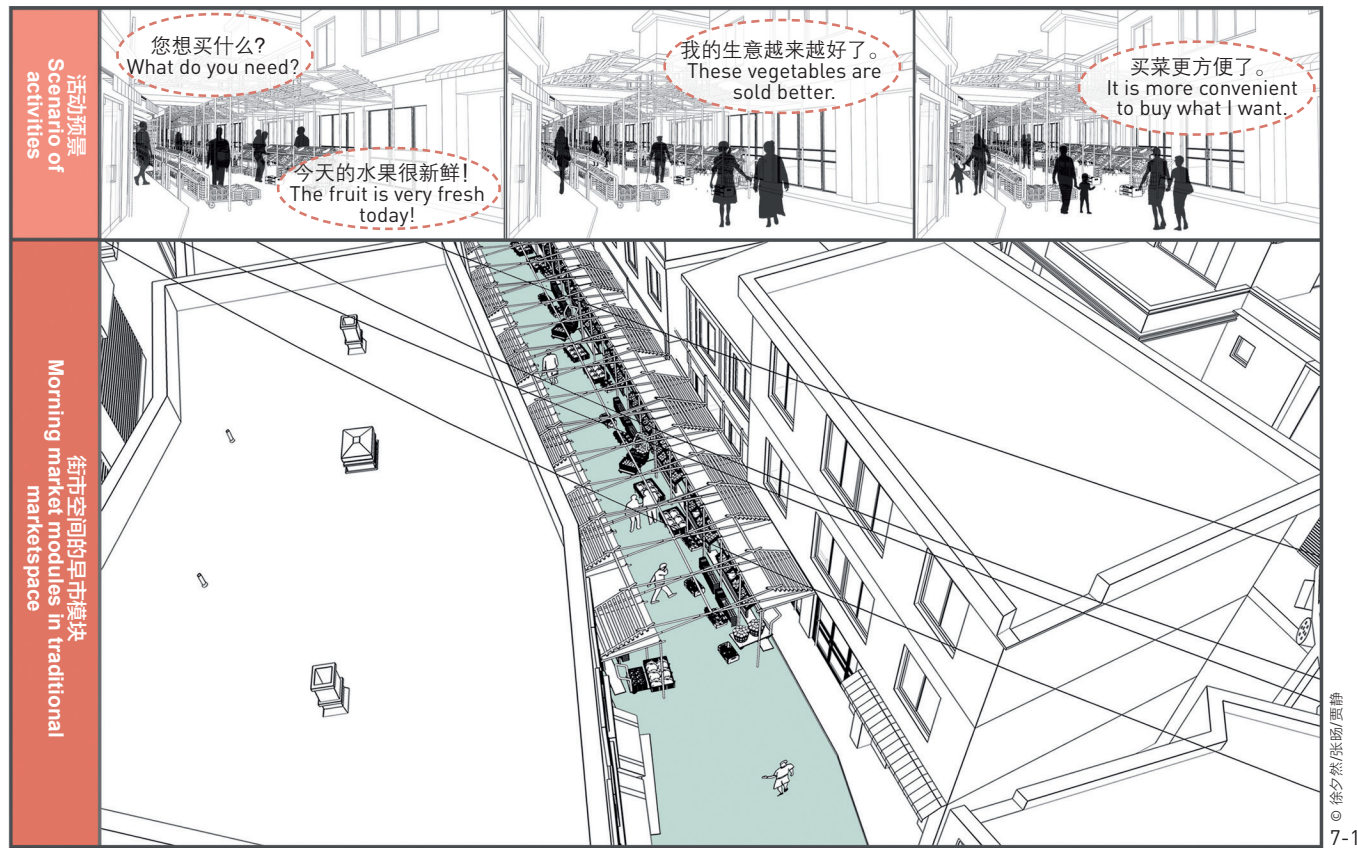

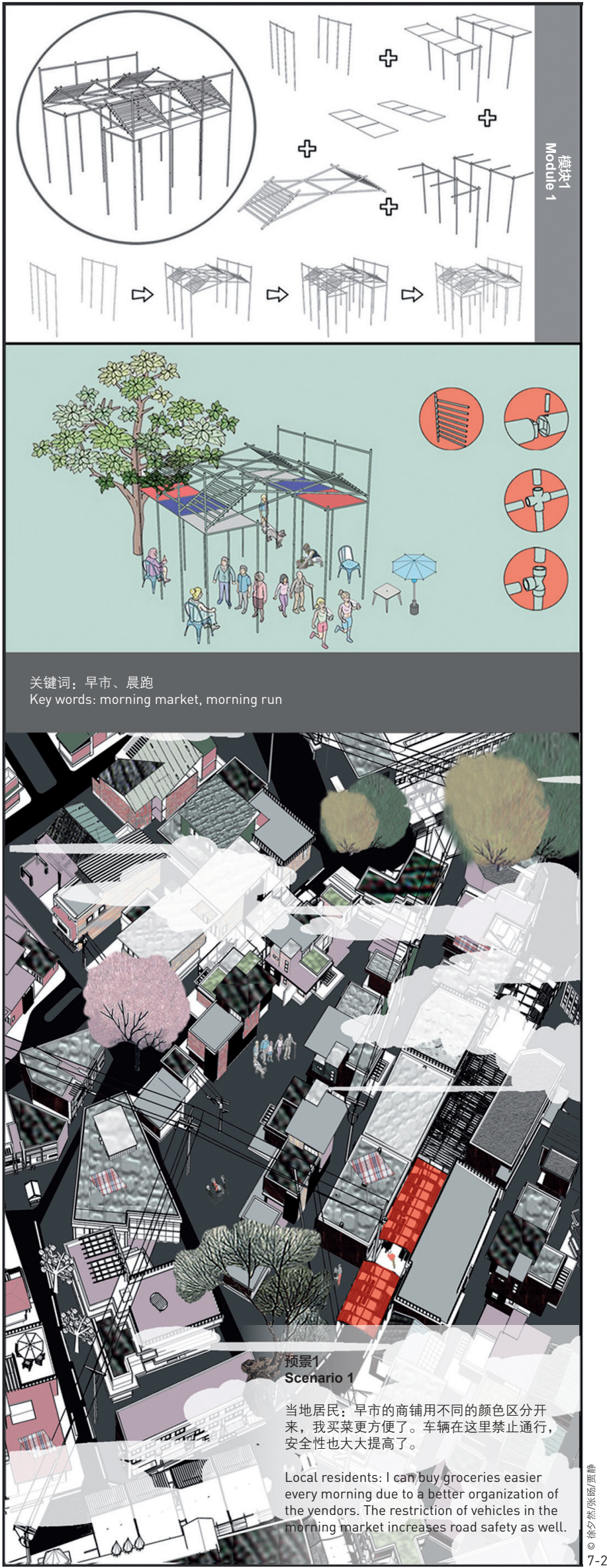




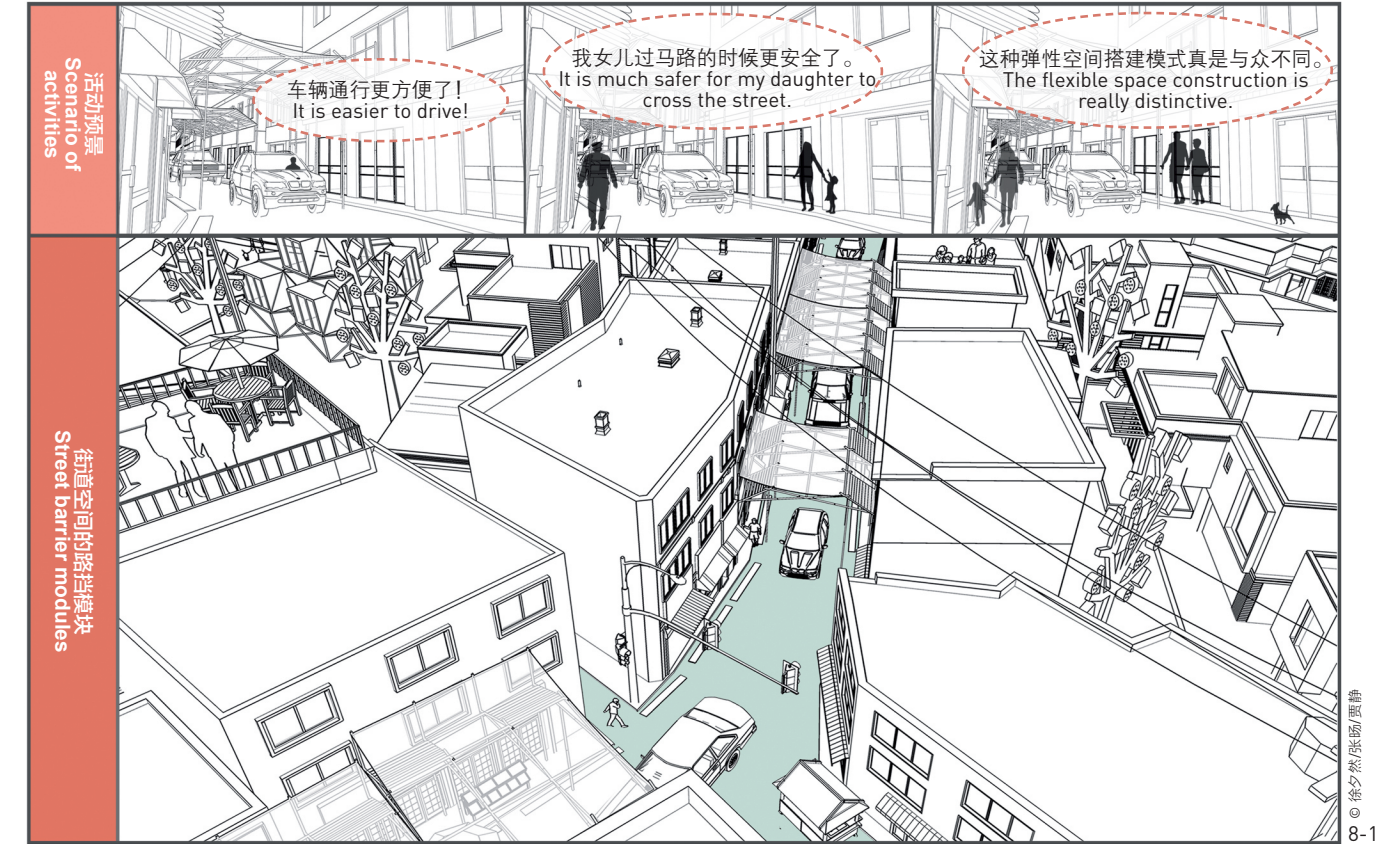

8-1. 街道空间的路挡模块

8-2. 搭建模式与效果图: 路挡模块不仅巧妙地将人车分流, 提高了 行车安全, 更为人们提供了明确的指引。

of uses allows the residents, shop owners, and visitors to share the site (Fig. 3). In recent years Haebangchon has declined, and the buildings, facilities, and amenities have become obsolete. The lack of a unified planning has led to several problems (Fig. 4), including:

(1) Lack of traffic planning for pedestrians and vehicles, which results in traffic jams and causes safety hazards during rush hours.

(2) Informal street vending that has caused conflicts between local residents, shop owners, and peddlers occupying the street.

(3) The site lacks quality recreational and public spaces. The existing amenities and facilities do not meet the daily demands of residents, shop owners and visitors.

\section{Design Strategies}

To address these problems, four strategies are proposed in this project (Fig. 5):
8-1. Street barrier modules

8-2. Construction model and rendering: The street barrier modules not only improve the traffic safety by separating pedestrians and vehicles, but also provide with clearer guide.

(1) Better integration of housing, businesses, and tourism

Social activity is an important consideration in public space design due to the interdependence of public space and social life. According to the diverse living, selling, and tourist activities in the neighborhood, the spatial functions are categorized into several types, including transportation, communication / social interaction, recreation, information access, commodity display, and trade in marketplace. The social activity classification helps develop specific spatial patterns to reorganize the usage and maintain the vitality.

(2) The street as a space with continuous, integrated, and multi-layered functions

To alleviate the conflicts caused by the limited street width and the mixed traffic, an idea of flexible construction is proposed, in which different renewals are
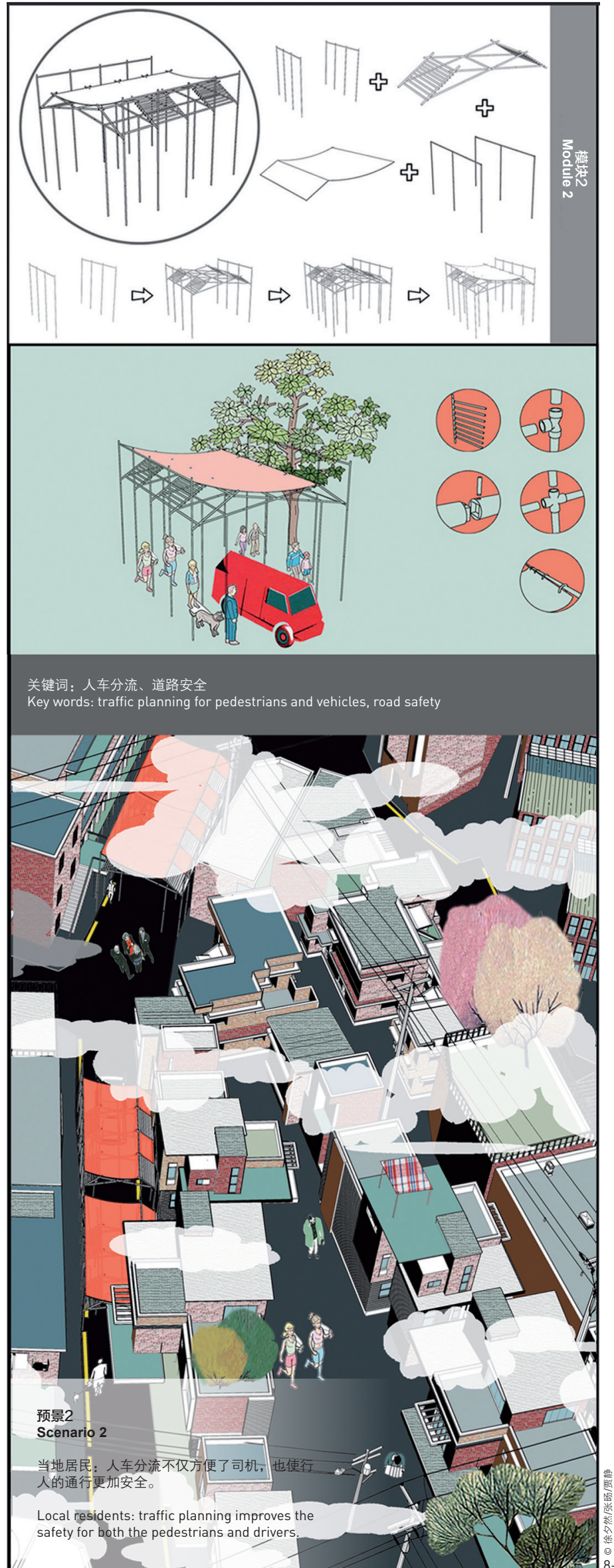
introduced according to the varying uses and conditions. As a result, a continuous, integrated, and multi-layered spatial system is created to improve the traffic environment and the lifestyle experience.

(3) Improving residents' living conditions and celebrating local culture

Haebangchon has a complex and diverse social and cultural environment, full of living vibrancy and historic memories. The project recommends extending residents' living space from the existing alley scale to a wider street scale. More space will allow residents to communicate with each other, help build a cohesive community, and provide visitors a genuine experience of the lifestyle in traditional neighborhoods.

(4) Establishing a data platform to motivate public engagement
The project establishes a flexible construction framework based on digital technologies, such as the Internet, $\mathrm{PPGIS}^{(3)}$, and virtual reality, which will be used as an application in mobile devices. With the assistance of PPGIS and the online platforms, we can identify the needs of local residents, shop owners, and visitors, from their digital footprints recorded when using the Internet. The analysis of these data may further help monitor the usage of the constructed modules. The application of virtual reality technology supported by data visualization could also help the users have a better understanding on the concept and participate in processes of construction, including site selection and design, which may lead to a more reasonable layout and construction of the modules (Fig. 6).
9-1. 街区空间的社交模块

9-2. 搭建模式与效果图: 社交模块可促进邻里交往, 为街区营造更加 宜人的生活和活动空间。

9-1. Social interaction modules

9-2. Construction model and rendering: The social interaction modules could help foster neighborhood relationship and create more pleasant living and activity spaces for all the neighborhood

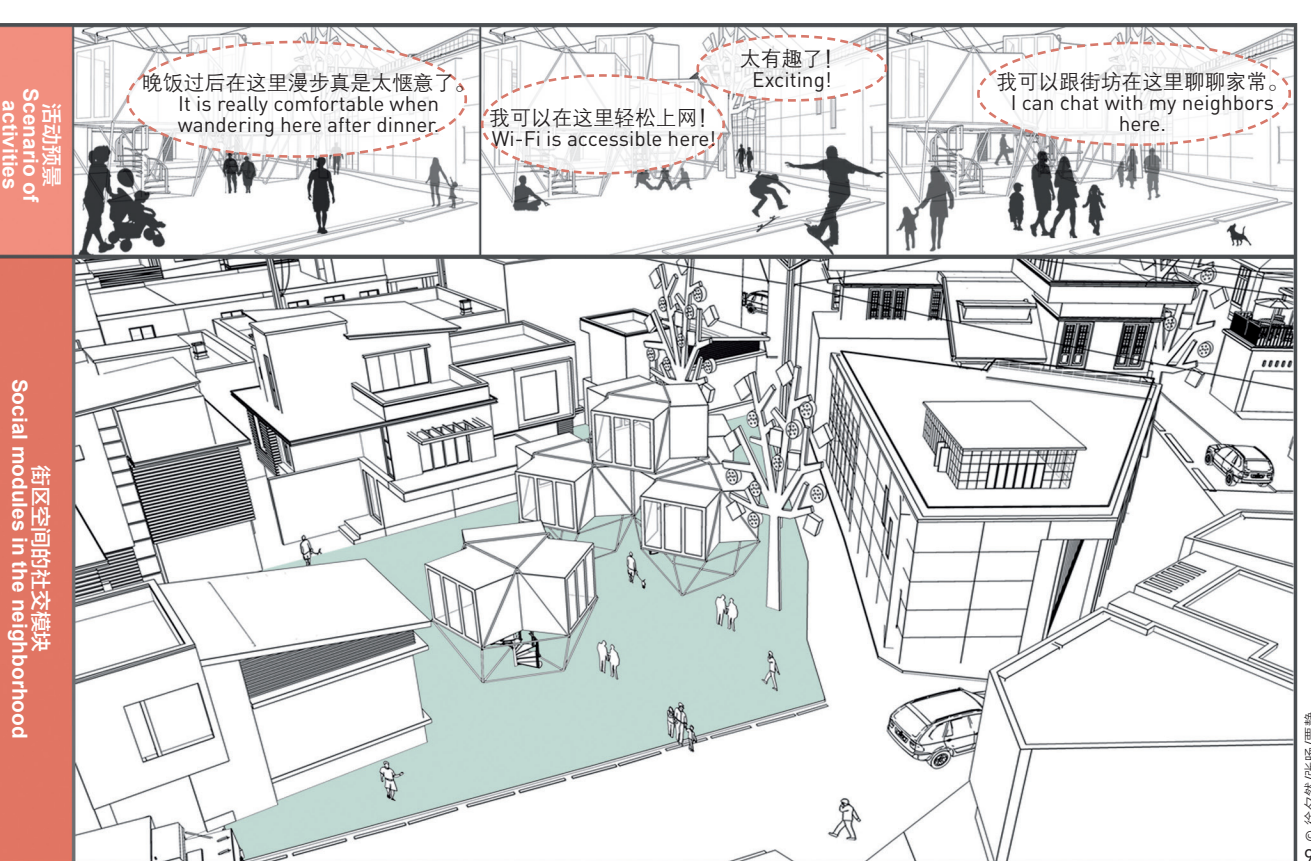

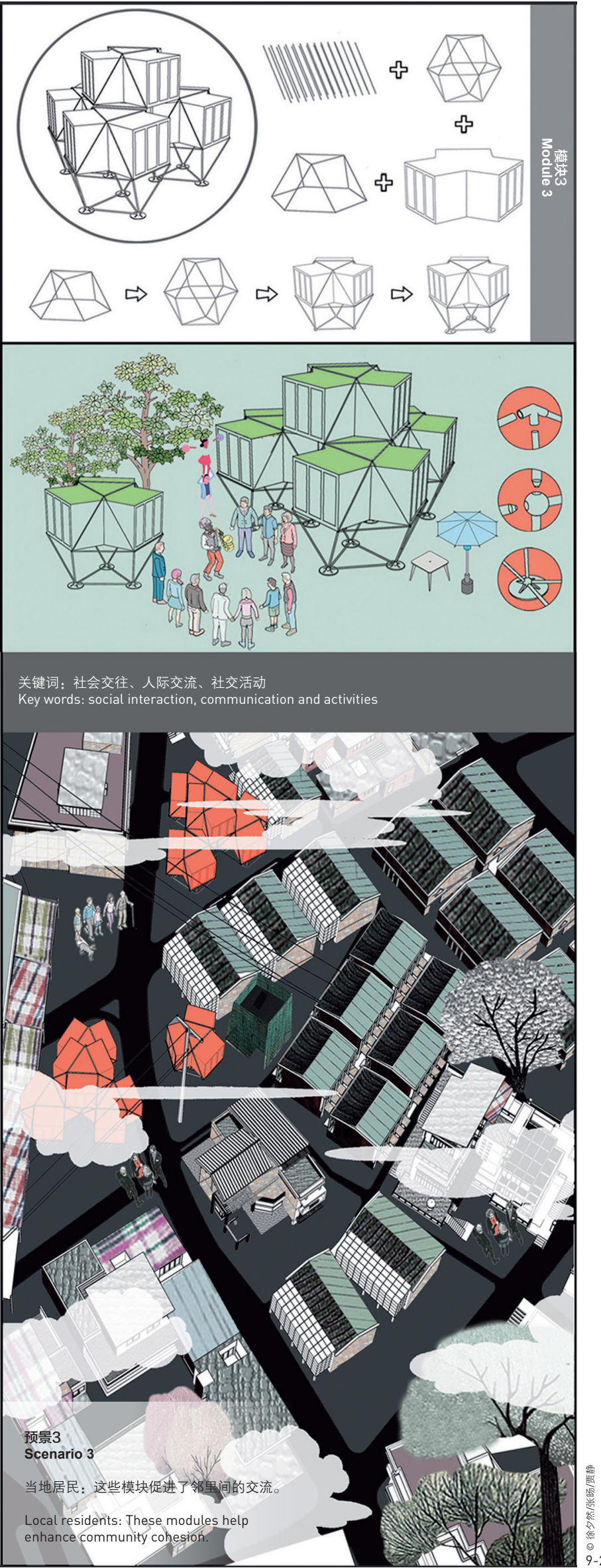




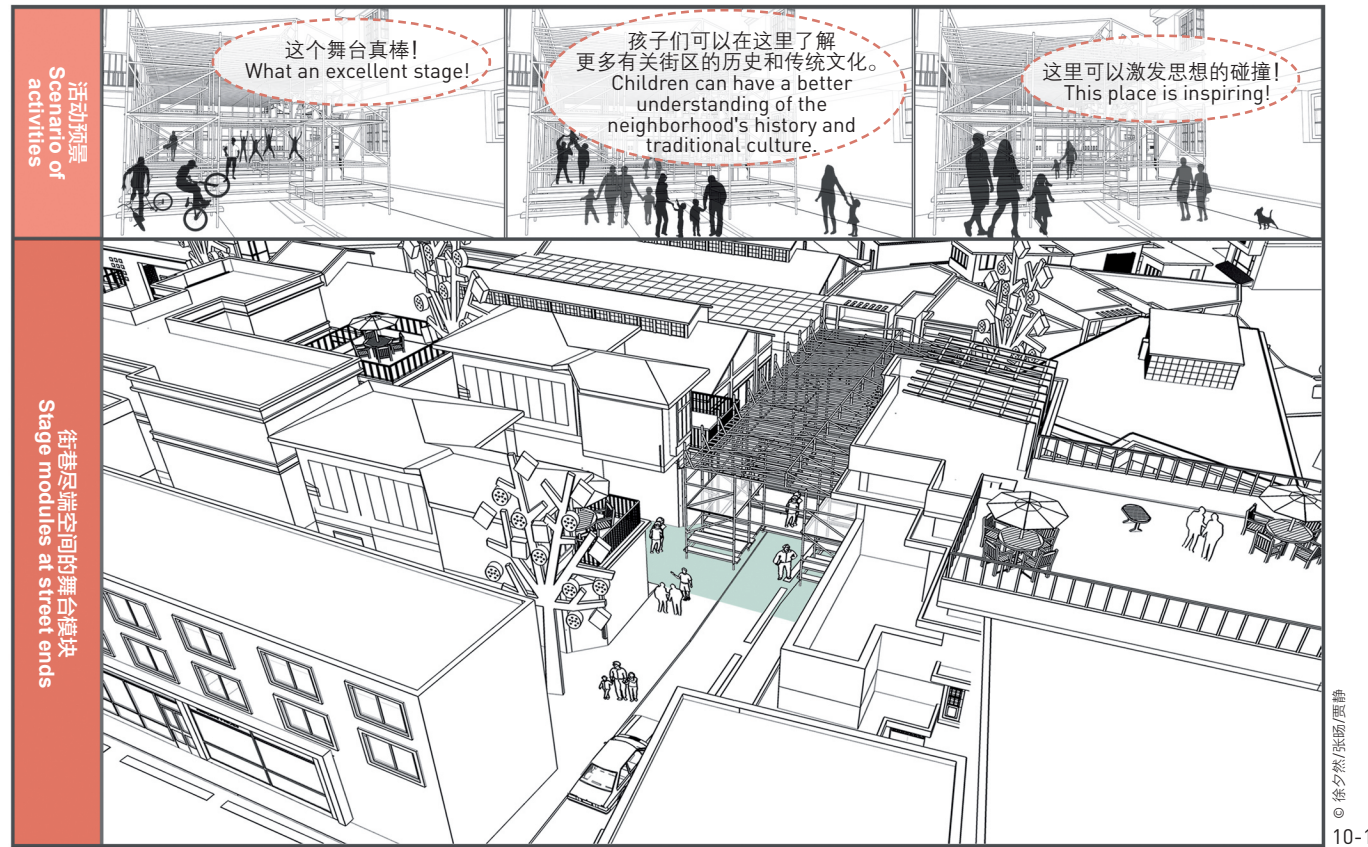

10-1. 街巷尽端空间的舞台模块

10-2. 搭建模式与效果图: 由多个模块构建组成的临时舞台既可为街 区提供庆祝、表演、集会的空间，也可为文化交流、节日纪 念品售卖等提供场所。

\section{Implementing Approaches}

The concept of flexible construction refers to a spatial intervention that can be applied to different types of space to better serve diverse lifestyle, social, and ecological demands. During the construction, bamboo poles, 1.5 meters in length, could be linked by --, L-, T-, F-, Y-, K-, and +-shaped metal connectors, together with elementary accessories, such as planks, awnings, and vertical planting bags. This type of construction is distinctive in its 1) applicability and versatility: the modules are multi-functional, cost-efficient, dismountable, movable, maneuverable and easy to be applied on different scales of space in the neighborhoods, and can be adjusted flexibly according to actual demands; 2) initiative: local residents and shop owners are encouraged to participate in public spatial transformation, which enhances community cohesion and sense of ownership; and 3)
10-1. Stage modules at street ends

10-2. Construction model and rendering: Temporary stages consisting of multiple modules could provide space for celebration, performance and gathering, and for cultural exchange and the sale of souvenirs. minimum intervention: the construction module is to minimize the intervention on the local physical and ecological environment (almost with no damage at all), to realize micro-renewal to the neighborhood.

Through an observation and analysis of residents' and visitors' behaviours, as well as the spatial patterns of the whole neighborhood, this project identifies five types of street space: public space for traditional markets, street space, and public space in the neighborhood, street ends, and alley space. Five types of construction modules are designed to meet different usage demands of these street spaces.

(1) Morning market modules in traditional marketplace: the morning market modules can be installed quickly, with prefabricated basic components and canopies in different colors. The colors represent different kinds of food and products which optimizes the market's

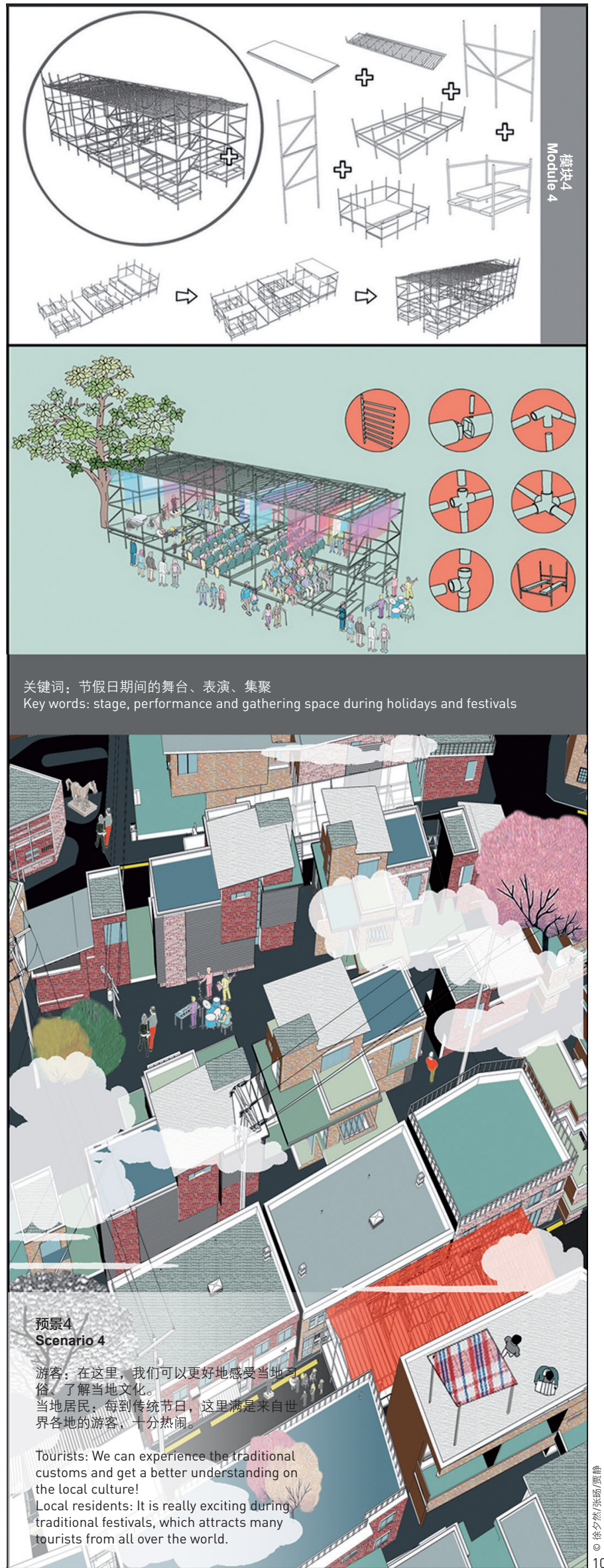


organization, making it more convenient for consumers (Fig. 7).

(2) Street barrier modules: after the morning market, street barriers and retractable awnings will be installed onto the prefabricated basic components to separate pedestrians and vehicles, which provides both with clearer guide and improves the traffic safety (Fig. 8).

(3) Social interaction modules in the neighborhood: due to the lack of quality public space in the neighborhood, social interaction modules are to be constructed in a larger area to provide adequate public space where residents can chat, rest, exercise, and read, helping foster the neighborhood relationships. Vertical planting is allowed in these modules to create a more pleasant living and activity space for all the neighborhood dwellers (Fig. 9).

(4) Stage modules at street ends: temporary stages consisting of multiple modules could be constructed to provide space for holiday celebration, performance, gathering, and other events, and for cultural exchange and the sale of souvenirs as well (Fig. 10).

(5) Small recreational space modules in alleys: recreation modules are installed with prefabricated basic components at corners of the alleys, forming a kind of small public space for users to stay or rest (Fig. 11).

\section{Conclusion}

Featured with strong adaptability and initiative, multiple functions, and minimal intervention, flexible construction could be adapted for various types of neighborhood or public space renewal according to the complexity and uniqueness of each space. This model could activate and improve the livability of traditional neighborhoods and help strengthen regional identity, creating a better urban life in traditional neighborhoods. LAF
11-1. 街巷微型空间的游息模块

11-2. 搭建模式与效果图: 通过在预制的基础构件上增加游慜模块 形成小型的公共空间, 可供使用者在此短暂停留休息。
11-1. Small recreational space modules in alleys

11-2. Construction model and rendering: Recreation modules are installed with prefabricated basic components, forming a small public space for users to stay or rest.

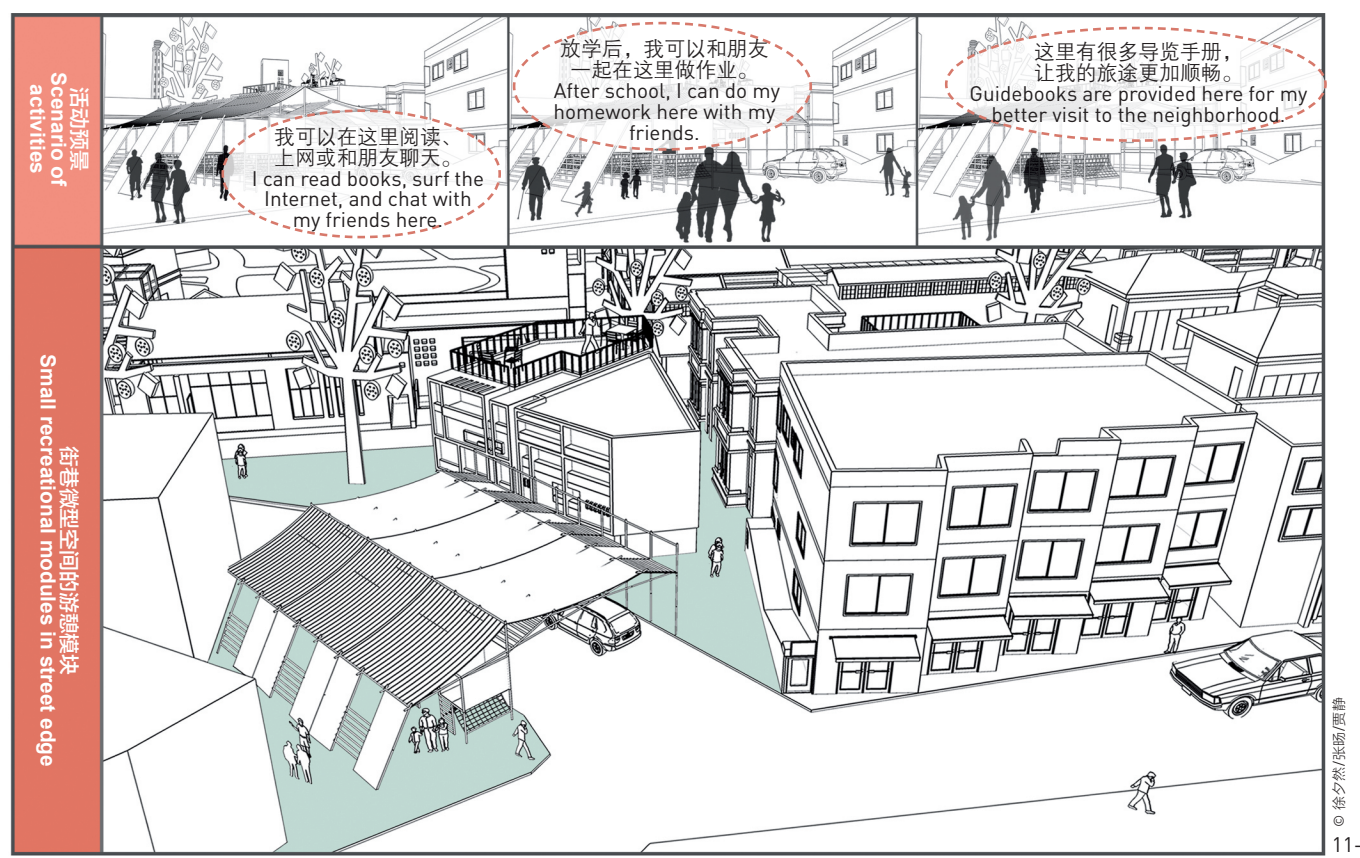

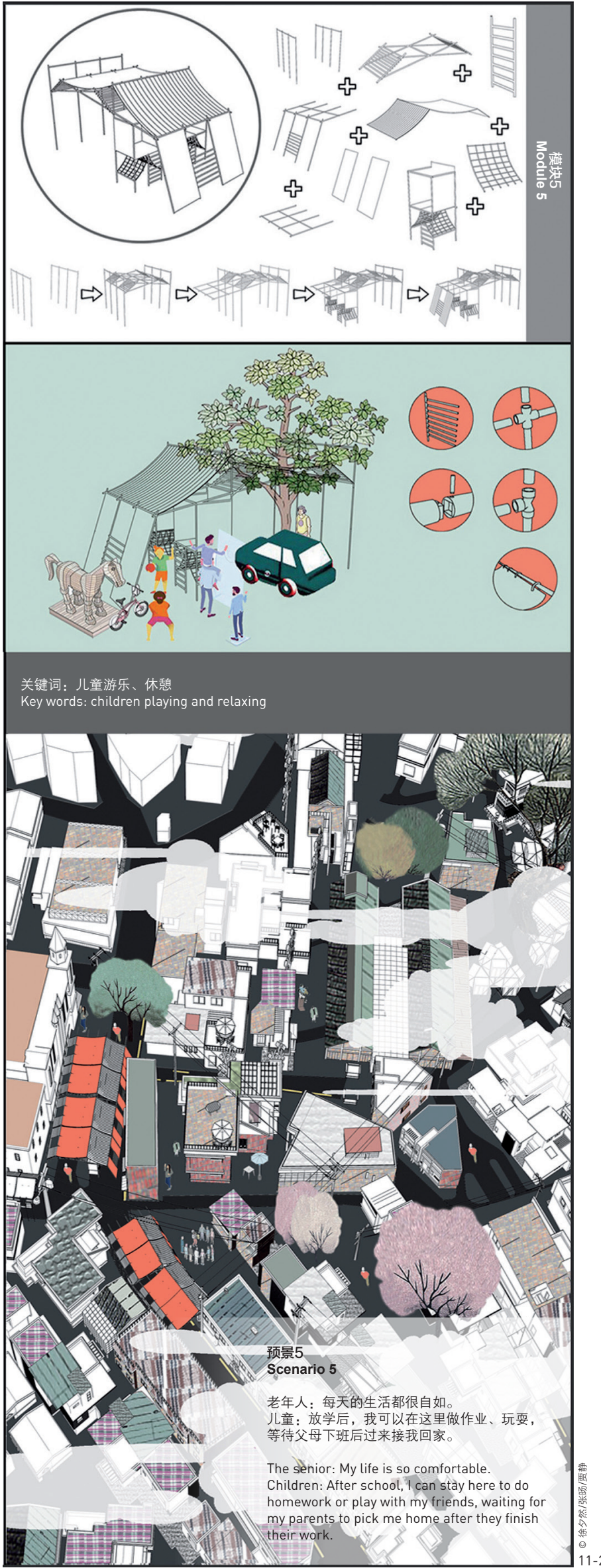

